\title{
Impact of pH on the single cell protein produced on okara-wheat grit substrates using Rhizopus oligosporus and Aspergillus oryzae
}

\author{
Mahmood Khan Yousufi \\ Department of Microbiology Jawaharlal Nehru College, Bhopal (M.P.) India
}

\begin{abstract}
The soymilk residue okara, is produced in large amount during soymilk production. Okara is a waste product for soymilk industries, so they face a big problem for its disposal. However, its nutritive composition; makes it suitable for producing different fermentable edible products, like single cell protein for human food and feed. The high moisture content of okara makes it unfavourable to be utilized alone. Therefore, it was used in combination with wheat grits. The combinations were inoculated with two standard food fungi viz. Rhizopus oligosporus and Aspergillus oryzae. The main concept of the present study was to examine SCP yield at different $p H$ ( $p H$ 3.0, 4.0, 5.0, 6.0 and 7.0). The maximum SCP production was obtained at $p H$ 5.0, producing $35.98 \%$ on fresh weight basis and $52.10 \%$ on dry weight basis for R. oligosporus and $36.20 \%$ on fresh weight basis and $50.41 \%$ on dry weight basis for A. oryzae.
\end{abstract}

Keywords: Single cell protein, Okara, Wheat grits, Rhizopus oligosporus, Aspergillus oryzae, $p H$.

\section{Introduction}

Soybean has been reported to be the oldest legume food known to mankind. Most of the South East Asian countries including China, Thailand, Indonesia, Japan etc. are known to be the major producers and consumers of this bean. The botanical name of soybean is "Glycine max". The white soybean was for the first time introduced in India as early as 1960. It was during this period when Nutri-nuggets were introduced in the Indian market. A large amount of okara is generated during soymilk production. About $1.1 \mathrm{~kg}$ wet okara is obtained from each $\mathrm{kg}$. of soybean processed for producing soymilk. The various steps involved in soymilk production process are shown in Fig. 1.

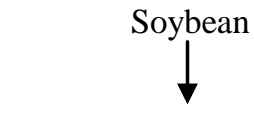

Soaked for $16 \mathrm{hr}$. at $20^{\circ} \mathrm{C}$

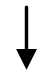

Soaked soybeans grinded with hot water for $20 \mathrm{~min}$.

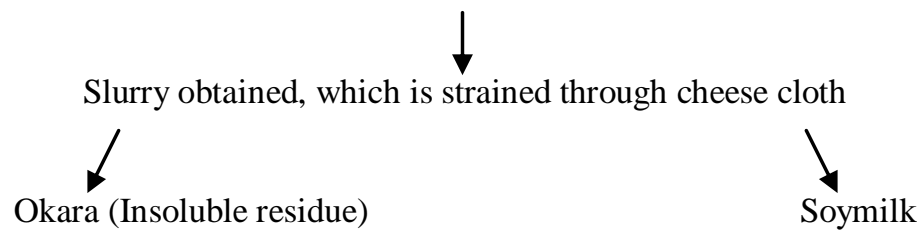

Fig.1. Process of soymilk production.

According to Shurtleff [9] and Aoyagi, 1979 the high moisture content of okara acts as a barrier in utilizing it for preparing different fermentable edible products. Yousufi [11] et al., 2003 successfully produced single cell protein using okara, by varying its moisture content. Nutritionally okara is rich in proteins, fats, carbohydrates and starch. It also contains minerals like calcium, iron, copper and zinc. In the year 2012, Yousufi [12] investigated on Inoculum size, Incubation temperature and Nucleic Acid Concentration on the Single Cell Protein produced by using Soymilk residue (Okara). Dimmling [1] and Seipenbusch in 1978 studied the raw material for the production of SCP. In vivo antioxidant activity of okara Kogi, a fermented okara, by Aspergillus oryzae was determined by Matsuo [4] 1997. Miyamura [5] et. al., 1988 detected fibrinolytic activity of okara fermented by Bacillus subtilis II. Hedenskog [2] and Mogren 1973 studied some methods of processing for single cell protein. Tofu and soymilk production was investigated by Shurtleff [9] and Aoyagi 1979. In 1975, Scrimshaw [8] suggested the consumption of single cell protein. The chemical composition of okara is shown in table 1. 
Impact of pH on the single cell protein produced on okara-wheat grit substrates using Rhizopus

TABLE 1. Chemical Composition of okara.

\begin{tabular}{|l|c|c|}
\hline \multirow{2}{*}{ Constitutent of okara } & \multicolumn{2}{|c|}{ Quantity (per 100g) } \\
\cline { 2 - 3 } & Fresh weight basis & Dry weight basis \\
\hline Protein & 4.66 & 19.91 \\
Fat & 1.96 & 8.37 \\
Carbohydrate & 2.23 & 9.53 \\
Starch & 0.66 & 2.82 \\
\hline
\end{tabular}

According to Righelato [7] and Elsworth (1970), okara can be successfully utilized for the production of some fermentation products. Taking into consideration the above evidence, the present investigation was undertaken. The moisture content of okara was reduced by using wheat grits. The wheat grits not only reduced the moisture content but also provided fermentable carbohydrates.

\section{Material And Methods}

Three materials were used in the present study i.e. okara, wheat grits and two standard food fungi viz. $R$. oligosporus and A. oryzae. Three combinations were prepared by mixing the substrates okara and wheat grits in particular ratios as given in Fig. 2. below:

\begin{tabular}{|c|c|c|}
\hline Okara (in grams) & Wheat grits (in grams) & Ratio \\
\hline 150 & 50 & $3: 1$ \\
100 & 100 & $1: 1$ \\
50 & 150 & $1: 3$ \\
\hline
\end{tabular}

Fig.2. Combinations of okara and wheat grits.

One hundred grams of each combination was weighed in five different flasks. The combinations were also supplemented with $2 \%$ urea, which was found to be the best nitrogen source. The $\mathrm{pH}$ of each combination was adjusted to 3.0, 4.0, 5.0, 6.0, and 7.0 using dilute acetic acid. Then the each combination was inoculated with the two fungal species; $R$.oligosporus and $A$. oryzae respectively. The flasks were finally incubated at $30^{\circ} \mathrm{C}$.

\section{Results And Discussion}

The results clearly indicated that maximum SCP yield was obtained at $\mathrm{pH} 5.0$ and minimum SCP yield was obtained at $\mathrm{pH}$ 3.0. The results obtained are given in table 2, 3, 4, 5, and 6. The findings with respect to optimum $\mathrm{pH}$ are in accordance with the earlier reports of Raimbault [6] et al., (1980) and Khare [3] et al., (1998).

The maximum SCP yield was obtained at 25\% moisture content on fresh weight basis at pH 5.0 for $R$. oligosporus $(35.98 \%)$ and for A. oryzae $(36.20 \%)$ whereas the maximum SCP yield was obtained at $60 \%$ moisture content on dry weight basis at pH 5.0 for R. oligosporus $(52.10 \%)$ and for A. oryzae $(50.41 \%)$.

TABLE 2. SCP yield at pH 3.0

\begin{tabular}{|l|l|l|l|}
\hline \multirow{2}{*}{ Organism } & Okara/Wheat grits & \multicolumn{2}{|c|}{ SCP yield (per 100g substrate) } \\
\cline { 3 - 4 } & & Fresh weight basis & Dry weight basis \\
\hline R. oligosporus & $150 / 50(60.5)$ & 11.12 & 25.20 \\
& $100 / 100(40.1)$ & 15.90 & 23.01 \\
& $50 / 150(25.0)$ & 19.01 & 21.53 \\
\hline A. oryzae & $150 / 50(59.9)$ & 11.55 & 27.99 \\
& $100 / 100(40.1)$ & 17.81 & 22.25 \\
& $50 / 150(25.1)$ & 20.10 & 21.90 \\
\hline
\end{tabular}

Note: Initial moisture contents are given in parentheses

TABLE 3. SCP yield at pH 4.0

\begin{tabular}{|l|l|l|l|}
\hline \multirow{2}{*}{ Organism } & \multirow{2}{*}{ Okara/Wheat grits } & \multicolumn{2}{|c|}{ SCP yield (per 100g substrate) } \\
\cline { 3 - 4 } & & Fresh weight basis & Dry weight basis \\
\hline R. oligosporus & $150 / 50(60.1)$ & 19.10 & 41.40 \\
& $100 / 100(40.1)$ & 20.99 & 40.25 \\
& $50 / 150(25.1)$ & 21.20 & 38.12 \\
\hline A. oryzae & $150 / 50(59.9)$ & 19.50 & 45.01 \\
& $100 / 100(40.0)$ & 20.10 & 44.90 \\
& $50 / 150(25.0)$ & 21.99 & 42.20 \\
\hline
\end{tabular}

Note: Initial moisture contents are given in parentheses. 
Impact of pH on the single cell protein produced on okara-wheat grit substrates using Rhizopus

TABLE 4. SCP yield at $\mathrm{pH}$ 5.0

\begin{tabular}{|l|l|l|l|}
\hline Organism & Okara/Wheat grits & \multicolumn{2}{|c|}{ SCP yield (per 100g substrate) } \\
\cline { 3 - 4 } & & Fresh weight basis & Dry weight basis \\
\hline \multirow{2}{*}{ R. oligosporus } & $150 / 50(60.5)$ & 20.17 & 52.10 \\
& $100 / 100(40.0)$ & 28.75 & 51.08 \\
& $50 / 150(25.0)$ & 35.98 & 48.57 \\
\hline \multirow{2}{*}{ oryzae } & $150 / 50(59.9)$ & 20.35 & 50.41 \\
& $100 / 100(40.1)$ & 29.41 & 47.90 \\
& $50 / 150(25.1)$ & 36.20 & 46.95 \\
\hline
\end{tabular}

Note: Initial moisture contents are given in parentheses

TABLE 5. SCP yield at $\mathrm{pH} 6.0$

\begin{tabular}{|l|l|l|l|}
\hline \multirow{2}{*}{ Organism } & Okara/Wheat grits & \multicolumn{2}{|c|}{ SCP yield (per 100g substrate) } \\
\cline { 3 - 4 } & & Fresh weight basis & Dry weight basis \\
\hline \multirow{3}{*}{ R. oligosporus } & $150 / 50(59.9)$ & 19.99 & 48.01 \\
& $100 / 100(40.1)$ & 26.25 & 43.90 \\
& $50 / 150(25.1)$ & 30.75 & 42.10 \\
\hline A. oryzae & $150 / 50(60.5)$ & 20.10 & 48.25 \\
& $100 / 100(40.0)$ & 25.75 & 47.50 \\
& $50 / 150(25.1)$ & 29.90 & 46.10 \\
\hline
\end{tabular}

Note: Initial moisture contents are given in parentheses

TABLE 6. SCP yield at pH 7.0

\begin{tabular}{|l|l|l|l|}
\hline Organism & Okara/Wheat grits & \multicolumn{2}{|c|}{ SCP yield (per 100g substrate) } \\
\cline { 3 - 4 } & & Fresh weight basis & Dry weight basis \\
\hline \multirow{3}{*}{ R. oligosporus } & $150 / 50(60.1)$ & 20.12 & 50.09 \\
& $100 / 100(40.1)$ & 24.50 & 50.10 \\
& $50 / 150(25.0)$ & 29.80 & 19.95 \\
\hline \multirow{3}{*}{ A. oryzae } & $150 / 50(60.5)$ & 20.15 & 50.25 \\
& $100 / 100(40.1)$ & 25.90 & 49.20 \\
& $50 / 150(25.1)$ & 30.10 & 48.40 \\
\hline
\end{tabular}

Note: Initial moisture contents are given in parentheses

\section{Conclusion}

In the present investigation it is concluded that varying $\mathrm{pH}$ causes changes in the SCP yield. The best $\mathrm{pH}$ value was established to be 5.0 for high yielding SCP.

\section{Acknowledgement}

The author is thankful to the Director, Mr. Aasif Zaki and Principal, DR. Y.P. Singh of Jawaharlal Nehru College, Bhopal (M.P.) India for providing library and laboratory facilities during the tenure of this investigation. 


\section{References}

[1] Dimmling, W. and Seipenbusch, R. 1978. Raw material for the production of SCP. Process Biochem. 13 (3) 9-15.34

[2] Hedenskog, G. and Mogren, H. 1973. Some methods of processing for single cell protein. Biotechnol. Bio eng. 15:129-142.

[3] Khare, S.K., Jha, Krishna and Gandhi, A.P. (1998). Glucomylase production by solid state fermentation from soypulp (okara). J. Dairying foods and HSci., 17: 85-90.

[4] Matsuo, M. 1997. In vivo antioxidant activity of okara Kogi, a fermented okara, By Aspergillus oryzae. Bioscience, Biotechnology and Biochemistry, 61:1968-1972

[5] Miyamura, H., Takenaka, Y. and Takenaka, T. 1988. Fibrinolytic activity of okara fermented by Bacillus subtilis II. The utility of okara, byproduct of the soybean processing industry. Journal of Japenese society of food science and technology (Nippon Shokuhin Kagaku Kogaku Kaishi), 45:100-107.

[6] Raimbault, M and Alazard, D. (1980). Cultural method to study fungal growth in solid fermentation . Eur. J. Appl. Microbial. Biotechnol., 9: 199-209.

[7] Righelato, R.H and Elsworth, R. (1970). Adv. In. Appl. Microbiology, 13:399-417.

[8] Scrimshaw. 1975. Single cell protein for human consumption - an overview. Insingle cell protein II. S.R. Tannenbaum and D.I.C. Wang (Editors) MIT Press, Cambridge Mass.

[9] Shurtleff W. and Aoyagi, A. 1979. Tofu and soymilk production. New Age Food Study Centre. Lafayette, CA, USA.

[10] Scrimshaw. 1975. Single cell protein for human consumption - an overview. Insingle cell protein II. S.R. Tannenbaum and D.I.C. Wang (Editors) MIT Press, Cambridge Mass

[11] Yousufi, Mahmood Khan, Khan, Shaukat Saeed and Jha, Krishna (2003). The effect of moisture content on the production of single cell protein using Rhizopus oligosporus and Aspergillus oryzae grown on okara- wheat grit combinations. Indian J. Applied \& Pure Bio. 18(1): 81-84.

[12] Yousufi, Mahmood Khan. (2012). Study of Inoculum size, Incubation temperature and Nucleic Acid Concentration on the Single Cell Protein produced by using Soymilk residue (Okara). International Journal of Scientific \& Engineering Research, 3(1): 1-4. 